\title{
Downregulation of DEC1 inhibits proliferation, migration and invasion, and induces apoptosis in ovarian cancer cells via regulation of $\mathrm{Wnt} / \boldsymbol{\beta}$-catenin signaling pathway
}

\author{
YUN YI $^{1}$, BING LIAO ${ }^{2}$, ZIWEN ZHENG ${ }^{1}$, XIAORONG YANG $^{1}$, YUNSHENG YANG $^{1}$, \\ YANFANG ZHOU $^{1}$, BUZHEN TAN ${ }^{3}$ and XINFENG YANG ${ }^{1}$ \\ ${ }^{1}$ Department of Gynecological Oncology, Cancer Hospital Affiliated to Nanchang University, Nanchang, \\ Jiangxi 330029; Departments of ${ }^{2}$ Otorhinolaryngology Head and Neck Surgery and ${ }^{3}$ Gynecology and Obstetrics, \\ The Second Affiliated Hospital of Nanchang University, Nanchang, Jiangxi 330000, P.R. China
}

Received December 13, 2019; Accepted June 17, 2020

DOI: $10.3892 /$ etm.2021.9803

\begin{abstract}
DEC1 has been reported to regulate the expression of multiple target genes, participate in cell differentiation, apoptosis, aging and the development and progression of numerous tumors, but the detailed effects and possible mechanisms of DEC1 in ovarian cancer (OC) remain unknown. The present study aimed to investigate the expression and mechanism of function of DEC1 in OC. The present results demonstrated that DEC1 was highly expressed in OC tissues and cell lines using reverse transcription-quantitative PCR, western blotting and immunohistochemistry, and high expression of DEC1 was negatively associated with the prognosis of patients with OC. In addition, knockdown of DEC1 significantly inhibited proliferation in SKOV3 and OVCAR3 cells compared with control. DEC1 knockdown also induced apoptosis and increased the expression of apoptosis-related proteins in OC cells. The results suggested that knockdown of DEC1 inhibited OC cell migration and invasion via regulation of epithelial-mesenchymal transition-related protein. It was also found that DEC1 knockdown significantly inhibited the Wnt/ $\beta$-catenin pathway. Collectively, the current results indicated that knockdown of DEC1 inhibited proliferation, migration and invasion, and induced apoptosis in OC cells via modulating the Wnt/ $\beta$-catenin signaling pathway. Thus, DEC1
\end{abstract}

Correspondence to: Dr Buzhen Tan, Department of Gynecology and Obstetrics, The Second Affiliated Hospital of Nanchang University, 1 Minde Road, Nanchang, Jiangxi 330000, P.R. China E-mail: yiyunkk66@163.com

Dr Xinfeng Yang, Department of Gynecological Oncology, Cancer Hospital Affiliated to Nanchang University, 519 Beijing East Road, Nanchang, Jiangxi 330029, P.R. China

E-mail: yangxinfengjx@163.com

Key words: ovarian cancer, differential embryo-chondrocyte expressed gene 1, proliferation, apoptosis, migration, invasion, Wnt $/ \beta$-catenin may participate in malignant progression of $\mathrm{OC}$, and may be a target for treatment and diagnosis of $\mathrm{OC}$.

\section{Introduction}

Ovarian cancer (OC) is one of the most common malignant tumors in gynecology (1). Compared with endometrial cancer, cervical cancer and vulvar cancer, the mortality rate of OC ranks first among the female genital tract malignant tumors, and its incidence is increasing year by year, which seriously threatens the life and health of women worldwide (2). For instance, the American Cancer Society estimated 22,530 new OC cases and 13,980 mortalities in the United States in 2019 (3). Anatomically, as OC is located in the deep structure of the pelvic cavity, there are no obvious signs of early pathological changes, which are difficult to detected (1). In addition, there is no specific diagnostic method, and thus $\sim 59 \%$ of patients with abdominal distension, dropsy or pain are in advanced stage at diagnosis. Therefore, insidious onset, late onset, high degree of malignancy, easy metastasis and poor prognosis are the main clinical features of OC (1). It has been shown that the 5-year survival rate of patients with early $\mathrm{OC}$ is $>75 \%$, while that of patients with advanced OC is only $29 \%$ (4). Cytoreductive surgery and cisplatin-based chemotherapy are standardized therapies for patients with advanced OC (5), and with the improvement of diagnosis and treatment, the 5-year survival rate of patients with OC increased from $36 \%$ in 1975 to $47 \%$ in $2014(6,7)$. However, $>50 \%$ of patients with advanced OC relapse within the first 5 years after treatment, resulting in cross-resistance to standardized therapy and other functional and structural unrelated chemotherapeutic drugs (8). Thus, the development of novel treatment strategies is urgently required to improve the treatment of patients with OC.

Differential embryo-chondrocyte expressed gene 1 (DEC1) is a helix-loop-helix transcription factor that directly binds to the class B type E-box in target genes, and is expressed to different degrees in most organs and tissues of the human body (9-11). DEC1 serves an essential role in various physiological functions of the body, including cell differentiation, cell cycle and circadian rhythm regulation, hypoxia, stress 
response and other processes $(12,13)$. It has been reported that $\mathrm{DEC} 1$ is abnormally expressed in several tumors and is related to the growth and apoptosis of tumors. For example, DEC1 has a positive anti-apoptotic effect on the proliferation of gastric cancer cells induced with hypoxia (14). Moreover, DEC1 negatively affects the expression of E-cadherin in HepG2 cells induced with hypoxia (15), while silencing DEC1 inhibits the proliferation of breast cancer by inducing cell cycle arrest in $\mathrm{S}$ phase (16). However, the possible effects and underlying mechanisms of DEC1 on OC are yet to be elucidated.

It has been revealed that DEC1 overexpression and knockdown inversely regulate the expression levels of $\beta$-catenin and phosphatidylinositol-4,5-bisphosphate 3-kinase catalytic subunit $\alpha$ in glucocorticoid-induced osteoporotic changes in SaoS-2 cells and mice (17). Furthermore, downregulation of DEC1 contributes to 1-methyl-4-phenyl-1,2,3,6-tetrahydropyridine-induced neurotoxicity by suppressing the PI3K/Akt/glycogen synthase kinase $3 \beta$ (GSK-3 $\beta$ ) pathway (18). The Wnt/ $\beta$-catenin signaling pathway is one of the most important signal transduction pathways in cells, and serves an essential role in regulating normal cell proliferation, movement, differentiation and tumorigenesis $(19,20)$. $\beta$-catenin, as a key molecule of the $\mathrm{Wnt} / \beta$-catenin pathway, accumulates in the cytoplasm and then translocates to the nucleus to activate downstream signal molecules in the nucleus $(21,22)$. Previous studies have shown that abnormal activation of the $\mathrm{Wnt} / \beta$-catenin pathway is closely corrected with the occurrence and development of numerous tumors. For instance, Wang et al (23) reported that after downregulation of odd-skipped related transcription factor 1 gene expression in H1299 cells, the Wnt/ $\beta$-catenin signaling pathway was inhibited and GSK-3 $\beta$ expression was significantly increased, while phosphorylated (p)-GSK-3 $\beta$, nuclear- $\beta$-catenin, cyclin D1, c-Myc and matrix metalloproteinase (MMP)-7 expression levels were significantly decreased, resulting in the reduction of proliferative and invasive abilities of H1299 cells (23). Furthermore, the Wnt pathway is activated in OC cells to promote $\beta$-catenin nuclear translocation, which subsequently acts on T-cell specific transcription factor (TCF) and lymphoid enhancer binding factor (LEF) transcription factors to induce the proliferation, differentiation and metastasis of OC stem cells (24). It has also been shown that in healthy colorectal tissues, the Wnt signaling pathway regulates the balance, proliferation and differentiation of intestinal stem cells (25).

The aim of the present study was to investigate the possible role and underlying mechanisms of DEC1 in OC. It was demonstrated that inhibition of DEC1 significantly inhibited proliferation, migration and invasion and induced apoptosis, which may be regulated by the $\mathrm{Wnt} / \beta$-catenin pathway. The results of the present study provide novel insights into the biological functions and underlying mechanisms of DEC1 in $\mathrm{OC}$, and may facilitate the development of a novel therapeutic target for diagnosing or treating $\mathrm{OC}$.

\section{Materials and methods}

Tissue samples. The present study involved 106 patients (aged 30-75 years; median age, 60 years) who were diagnosed with $\mathrm{OC}$ in the Gynecology Department of Jiangxi Cancer Hospital Affiliated to Nanchang University (Nanchang, China) between
September 2015 and September 2018. No chemoradiotherapy was performed before the operation. OC tissues and corresponding adjacent healthy tissue were resected from each patient and immediately placed in a liquid nitrogen flash freezer at $-80^{\circ} \mathrm{C}$. None of the patients had received any chemotherapy or radiotherapy. All tumors were histologically classified as well (grade 1), moderately (grade 2), poorly (grade 3) and others (grade 4) according to the Edmondson-Steiner grading system (26). This study has obtained approval from the Jiangxi Cancer Hospital Medical Ethics Committee and oral informed consent was obtained from all patients.

Cell lines. In total, two OC cell lines (SKOV3 and OVCAR3) and a normal human ovarian epithelial cell line (IOSE80) were purchased from Stem Cell Bank, Chinese Academy of Sciences. RPMI-1640 (Gibco; Thermo Fisher Scientific, Inc.) medium containing $1 \%$ penicillin/streptomycin (Sigma-Aldrich; Merck KGaA) and 10\% FBS (Gibco; Thermo Fisher Scientific, Inc.) was used for cell culture in a $5 \% \mathrm{CO}_{2}$ incubator maintained at $37^{\circ} \mathrm{C}$.

Cell transfection. Short hairpin (sh)RNA targeting DEC1 (shEDC1) and its negative control (NC shRNA) were synthesized by Shanghai GenePharma Co., Ltd., and subsequently inserted into pSuper plasmid (Shanghai GenePharma Co., Ltd.) using DNA recombination technology. shEDC1 or NC (100 ng) was transfected in SKOV3 and OVCAR3 cells using Lipofectamine ${ }^{\circledR} 2000$ (Invitrogen; Thermo Fisher Scientific, Inc.) according to the manufacturer's protocol. Transfected cells were cultured for $48 \mathrm{~h}$, then the subsequent functional experiments were performed.

Cell Counting Kit (CCK)-8 assay. Viability of transfected OC cells was evaluated using CCK-8 assay (Beyotime Institute of Biotechnology), according to the manufacturer's instructions. SKOV3 and OVCAR3 cells ( $1 \times 10^{4} /$ well) were seeded in 96-well plates and incubated for $0,24,48$ and $72 \mathrm{~h}$ at $37^{\circ} \mathrm{C}$. Then, cells were incubated with $10 \mu \mathrm{lCCK}-8$ solution for $4 \mathrm{~h}$ at $37^{\circ} \mathrm{C}$. The optical density (OD) was measured using a microplate at $490 \mathrm{~nm}$ (Multiskan MK3; Thermo Fisher Scientific, Inc.). Each experiment was performed in triplicate.

EdU assay. The proliferation of OC cells after transfection was determined using a EdU assay. Transfected SKOV3 and OVCAR3 cells (1x104/well) were seeded in 96-well plates and cultured for $48 \mathrm{~h}$. Then, cells were fixed with $4 \%$ paraformaldehyde at room temperature for $30 \mathrm{~min}$ and $0.5 \%$ Triton X-100 was used to permeabilize the nuclear membrane at room temperature for $10 \mathrm{~min}$. Cells were blocked with goat serum (Gibco; Thermo Fisher Scientific, Inc.) at room temperature for $1 \mathrm{~h}$, and then The nuclei were counterstained for $15 \mathrm{~min}$ at room temperature with $100 \mathrm{ng} / \mathrm{ml}$ DAPI (Thermo Fisher Scientific, Inc.). EdU-positive cells were observed using a fluorescence microscope (magnification, x200; Olympus Corporation). Each experiment was performed in triplicate.

TUNEL assay. The OC tissue slices $(4 \mu \mathrm{m})$ were washed with PBS and then fixed at room temperature for 30 min with $4 \%$ paraformaldehyde. After washing once with PBS, the slices were incubated with $0.1 \%$ Triton $\mathrm{X}-100$ at room temperature 
for $2 \mathrm{~min}$ and then washed once with PBS. Subsequently, 3\% $\mathrm{H}_{2} \mathrm{O}_{2}$ was used for incubation (5 min) at room temperature. Slides was rinsed and incubated with $50 \mu 1 \mathrm{TUNEL}$ at $37^{\circ} \mathrm{C}$ overnight. After rinsing with PBS, the TUNEL reaction was visualized using chromogenic staining with 3,3'-diaminobenzidine (DAB; Sigma-Aldrich; Merck KGaA). The nuclei were counterstained for $15 \mathrm{~min}$ at room temperature with $100 \mathrm{ng} / \mathrm{ml}$ DAPI (Thermo Fisher Scientific, Inc.). Neutral gum was used to seal the slides. A fluorescent microscope (magnification x100; Leica Microsystems, Inc.) was used to observe the slides and the TUNEL-positive SKOV3 and OVCAR3 cells were calculated in ImageJ software (version 1.48; National Institutes of Health). Three visual fields were observed. All measurements were performed three times to ensure accuracy. Each experiment was performed in triplicate.

Wound healing assay. Transfected SKOV3 and OVCAR3 cells were treated as aforementioned before monolayer inoculation into a 6 -well culture plate at the density of $5 \times 10^{4}$ cells/well. The supernatant fluid was removed when SKOV3 and OVCAR3 cells were highly confluent $(>90 \%)$. Scratches were made using a sterile pipette tip, with the scratch width remaining the same. Then, the culture solution was replaced with FBS-free RPMI-1640 solution. After continuous culture for $48 \mathrm{~h}$, Images were obtained using an optical microscope (magnification, x100; BX-51; Olympus Corporation). The scratch width of SKOV3 and OVCAR3 cells was measured to calculate the wound healing rate in Image J software (version 1.48; National Institutes of Health). Each experiment was performed in triplicate.

Transwell invasion assay. Matrigel stored at $-20^{\circ} \mathrm{C}$ was thawed overnight at $2-8^{\circ} \mathrm{C}$. Transfected SKOV3 and OVCAR3 cells (1x10 3 cells/well) were transferred to 24 -well Transwell inserts (5 $\mu \mathrm{m}$; Corning, Inc.) for monolayer inoculation or inoculated into the upper chamber loaded with Matrigel using serum-free medium. RPMI-1640 solution containing 10\% FBS (v/v) (Gibco; Thermo Fisher Scientific, Inc.) was added in the lower chamber, and the cells were cultured at $37^{\circ} \mathrm{C}$ for $48 \mathrm{~h}$. Then, the Matrigel and the cells that had not invaded the lower chamber were removed using test paper. Cells passing through the Transwell membrane were counted after fixing at room temperature for $30 \mathrm{~min}$ with $4 \%$ paraformaldehyde, and then stained with $1 \%$ crystal violet at room temperature for $10 \mathrm{~min}$. Images were obtained using an light microscope (magnification, x100; BX-51; Olympus Corporation). The experiment was replicated three times independently under the same conditions.

RNA extraction and reverse transcription-quantitative $P C R$ $(R T-q P C R)$ analysis. Total RNA was extracted from OC tissues and cell lines using TRIzol ${ }^{\circledR}$ reagent (Thermo Fisher Scientific, Inc.), and then reverse-transcribed into cDNA at $55^{\circ} \mathrm{C}$ for $10 \mathrm{~min}$ using PrimeScript RT-PCR kit (Takara Biotechnology Co., Ltd.). The mRNA levels were quantified by RT-qPCR with the StepOne ${ }^{\mathrm{TM}}$ Real-Time PCR System (Thermo Fisher Scientific, Inc.) using SYBR ${ }^{\circledR}$ Premix Ex Taq $^{\mathrm{TM}}$ (Takara Biotechnology Co., Ltd.). The reaction conditions were as follows: $94^{\circ} \mathrm{C} 3 \mathrm{~min}$; 30 cycles of $94^{\circ} \mathrm{C}$ for $45 \mathrm{sec}, 57^{\circ} \mathrm{C}$ for $45 \mathrm{sec}, 72^{\circ} \mathrm{C}$ for $45 \mathrm{sec}$; and final extension at $72^{\circ} \mathrm{C}$ for $10 \mathrm{~min}$. Primer sequences used were designed as follows: DEC1 forward, 5'-TTGCTTTCCTTCCTCG-3' and reverse, 5'-CACACACACCCTGCCTCTGC-3'; and GAPDH forward, 5'-GAAGGTGAAGGTCGGAGTCA-3' and reverse, 5'-AGGGGCCATCCACAGTCTTC-3'. All target gene transcripts were normalized to GAPDH using the $2^{-\Delta \Delta \mathrm{Cq}}$ method (27). Each experiment was performed in triplicate.

Western blotting. Proteins from transfected OC tissues and cell lines were lysed with RIPA lysis buffer (Bio-Rad Laboratories, Inc.), and total protein concentrations were determined using a bicinchoninic acid protein assay kit (Beyotime Institute of Biotechnology). Equivalent samples $(30 \mu \mathrm{g})$ were separated using $10 \%$ SDS-PAGE and then transferred onto a PVDF membrane for $2 \mathrm{~h}$. Membranes were blocked with $5 \%$ non-fat skim milk in TBS-0.1\% Tween-20 buffer at $25^{\circ} \mathrm{C}$ for $1 \mathrm{~h}$ and incubated with the primary antibodies at $4^{\circ} \mathrm{C}$ overnight: DEC1 (cat. no. ab97525; 1:1,000), caspase-3 (cat. no. ab197202; 1:1,000), cleaved caspase-3 (cat. no. ab2302; 1:1,000), poly(ADP-ribose) polymerase 1 (PARP; cat. no. ab74290; 1:1,000), cleaved PARP (cat. no. ab32064; 1:1,000), E-cadherin (cat. no. ab1416; 1:1,000), vimentin (cat. no. ab92547; 1:1,000), $\alpha$-smooth muscle actin ( $\alpha$-SMA; cat. no. ab32575; 1:1,000), glycogen synthase kinase $3 \beta$ (GSK-3 $\beta$; cat. no. ab93926; $1: 1,000$ ), p-GSK-3 $\beta$ (cat. no. ab75814; 1:1,000), $\beta$-catenin (cat. no. ab32572; 1:1,000) and GAPDH (cat. no. ab181602; 1:1,000). Then, the HRP-conjugated rabbit anti-mouse IgG H\&L antibodies (1:2,000; cat. no. ab6728) or HRP-conjugated goat anti-rabbit IgG H\&L antibodies (1:2,000; cat. no. ab6721) was used at room temperature for $2 \mathrm{~h}$. All antibodies were purchased from Abcam. The relative band density was determined using the Bio-Rad Imaging System (Bio-Rad Laboratories, Inc.) with an ECL western blotting substrate kit (Tanon Science and Technology Co., Ltd.). GAPDH was used as internal reference. Protein bands were visualized using an ECL kit (Beyotime Institute of Biotechnology) and quantified using ImageJ software (version 4.3; National Institutes of Health). Each experiment was performed in triplicate.

Immunohistochemical analysis. OC tissues and corresponding adjacent healthy tissues samples were fixed at room temperature for $30 \mathrm{~min}$ in $10 \%$ neutral buffered formalin and embedded in paraffin wax. Slides with a thickness of $4 \mu \mathrm{m}$ were deparaffinized with $100 \%$ xylene, rehydrated with anhydrous, $95,75 \%$ ethanol and incubated with $30 \% \mathrm{H}_{2} \mathrm{O}_{2}$ at $37^{\circ} \mathrm{C}$ for $10 \mathrm{~min}$. Antigen repair was performed by using $10 \mathrm{mM}$ citric acid at $95^{\circ} \mathrm{C}$ for $15 \mathrm{~min}$. After cooling, the sections were blocked at room temperature for $30 \mathrm{~min}$ using $10 \% \mathrm{FBS}$. Then, slides were incubated at $4^{\circ} \mathrm{C}$ overnight with DEC1 antibody (1:1,000; cat. no. ab97525; Abcam). Subsequently, the sections were incubated with biotin-conjugated goat anti-rabbit IgG secondary antibody (1:1,000; cat. no. ab205718; Abcam) at $37^{\circ} \mathrm{C}$ for $30 \mathrm{~min}$. DAB was used as chromogenic agent. After washing with PBS, the sections were counterstained with hematoxylin, dehydrated with ethanol (70, 80, 90, 95 and 100\%) and xylene, and then sealed with neutral resin. Images were obtained using a fluorescence microscope (magnification, x100; FSX100; Olympus Corporation). In total, five representative visual fields were randomly selected to calculate the percentage of 
A

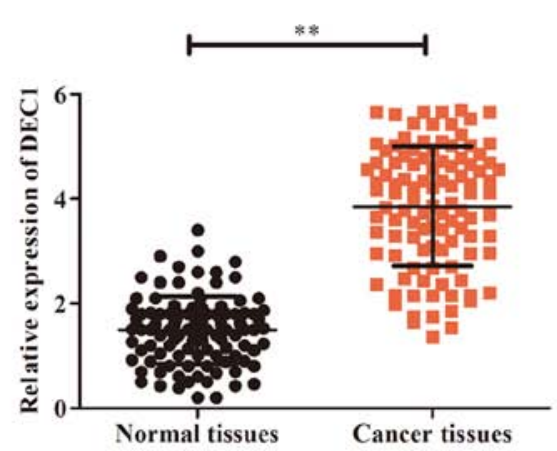

B Normal tissues $1 \quad$ Normal tissues 2 Normal tissues 3

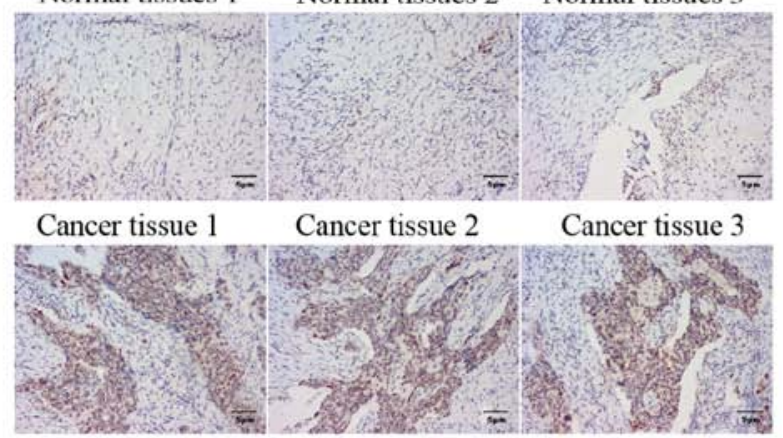

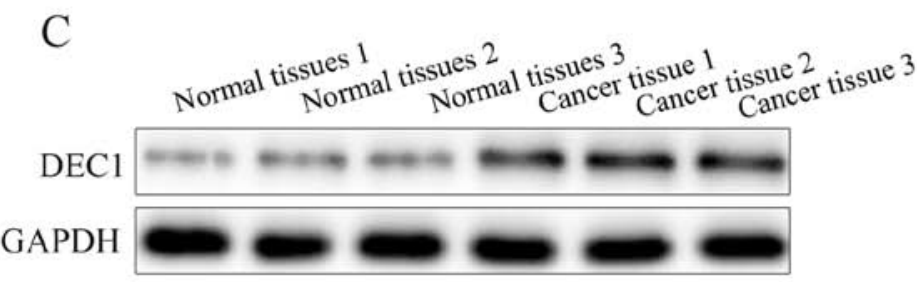

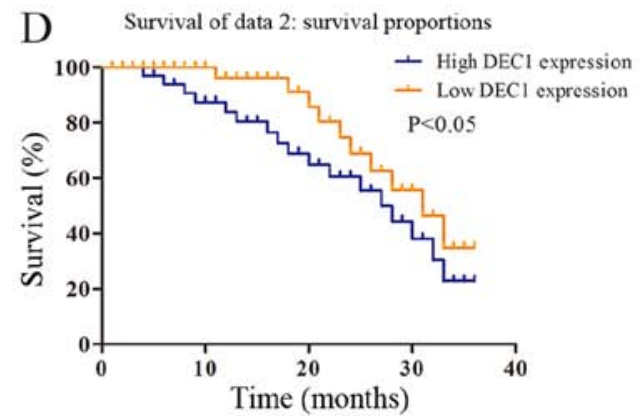

Figure 1. DEC1 is upregulated in OC tissues. Expression of DEC1 in OC tissues and corresponding adjacent healthy tissues was detected using (A) reverse transcription-quantitative PCR, (B) immunohistochemical and (C) western blotting. (D) Overall survival of 50 patients with high DEC1 expression and 50 patients with low DEC1 expression. Scale bars, $5 \mu \mathrm{m}$. ${ }^{* *} \mathrm{P}<0.01$. DEC1, differential embryo-chondrocyte expressed gene 1; OC, ovarian cancer.

positive cells. The results of DEC1 protein positive staining were indicated by cells with brown granules. The adjacent healthy tissues were used as the control.

Statistical analysis. SPSS 20.0 (IBM Corp.) was used for statistical analysis. The survival curve was constructed using the Kaplan-Meier method and compared using the log-rank test. Data are presented as the mean \pm standard deviation. Categorical data were analyzed using a $\chi^{2}$ test. Intergroup comparison was examined using a paired t-test (two groups) or one-way ANOVA ( $\geq 3$ groups), followed by Bonferroni test. $\mathrm{P}<0.05$ was considered to indicate a statistically significant difference.

\section{Results}

DECl is upregulated in OC tissues. To investigate the possible effects and mechanisms of DEC1 on the occurrence of OC, RT-qPCR was performed to assess DEC1 mRNA expression in OC tissues $(\mathrm{n}=106)$ and adjacent healthy tissues $(n=106)$. The results demonstrated that DEC1 was significantly upregulated in OC tissues compared with adjacent healthy tissues (Fig. 1A). Subsequently, the association between DEC1 level and the progression of OC was assessed. The general features of 106 patients with OC were presented and the association between the expression of DEC1 and those features was analyzed. It was found that the expression of DEC1 was positively associated with tumor size and metastasis (Table I).

Immunohistochemical and western blotting assays were conducted to evaluate the protein expression of DEC1 in
OC tissues ( $n=3)$ and adjacent healthy tissues $(n=3)$, and it was identified that the expression of DEC1 was markedly higher in OC tissues compared with adjacent healthy tissues (Fig. 1B and C). Furthermore, the Kaplan-Meier survival analysis indicated that patients with high DEC1 expression had a significantly poorer prognosis compared with those with a low expression (Fig 1D). Thus, these data suggested that DEC1 was upregulated in $\mathrm{OC}$ and that high expression of DEC1 predicted poor prognosis of patients with OC.

DEC1 is upregulated in OC cell lines. Next, DEC1 expression was assessed in OC cell lines, including SKOV3 and OVCAR3 using western blotting and RT-qPCR assays. The protein and mRNA expression levels of DEC1 were upregulated in SKOV3 and OVCAR3 cells compared with IOSE80 cells (Fig. 2A and B). In addition, shRNA was used to establish stable DEC1 knockdown SKOV3 and OVCAR3 cells, and transfection efficiency was determined using western blotting. It was found that shDEC1 significantly inhibited the expression of DEC1 in both SKOV3 and OVCAR3 cells compared with ISOE80 cells (Fig. 2C).

Knockdown of DECl inhibits proliferation of OC cells. Firstly, a CCK-8 assay was performed to evaluate the viabilities of SKOV3 and OVCAR3 cells transfected with shDEC1 for 0, 24, 48 and $72 \mathrm{~h}$. Knockdown of DEC1 significantly inhibited the viabilities of both cell lines compared with negative control (Fig. 3A and B). Moreover, an EdU assay was used to assess the suppressive effects of shDEC1 on the proliferation of SKOV3 and OVCAR3 cells. It was demonstrated that knockdown of DEC1 could significantly decrease the 
Table I. Association between DEC1 expression and clinicopathologic of patients with ovarian cancer.

DEC1 expression

\begin{tabular}{|c|c|c|c|c|}
\hline Characteristics & Case number & High $(n=50)$ & Low $(\mathrm{n}=50)$ & P-value \\
\hline Age, years & & & & 0.594 \\
\hline$\leq 60$ & 41 & 23 & 1 & \\
\hline$>60$ & 59 & 27 & 32 & \\
\hline Tumor size, $\mathrm{cm}$ & & & & $0.026^{\mathrm{a}}$ \\
\hline$\leq 5$ & 35 & 17 & 36 & \\
\hline$>5$ & 65 & 33 & 14 & \\
\hline Distant metastasis & & & & $0.037^{\mathrm{a}}$ \\
\hline Yes & 54 & 38 & 18 & \\
\hline No & 46 & 12 & 32 & \\
\hline Differentiation grade & & & & 0.381 \\
\hline $\mathrm{I}+\mathrm{II}$ & 69 & 26 & 31 & \\
\hline $\mathrm{III}+\mathrm{IV}$ & 31 & 24 & 19 & \\
\hline Histological grade & & & & 0.219 \\
\hline Well and moderately & 56 & 29 & 27 & \\
\hline Poorly and others & 44 & 21 & 23 & \\
\hline Clinical stage & & & & 0.321 \\
\hline $\mathrm{I}+\mathrm{II}$ & 49 & 16 & 20 & \\
\hline $\mathrm{III}+\mathrm{IV}$ & 51 & 34 & 30 & \\
\hline
\end{tabular}

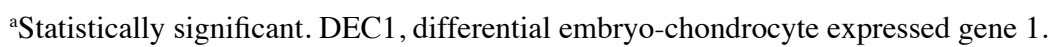

A
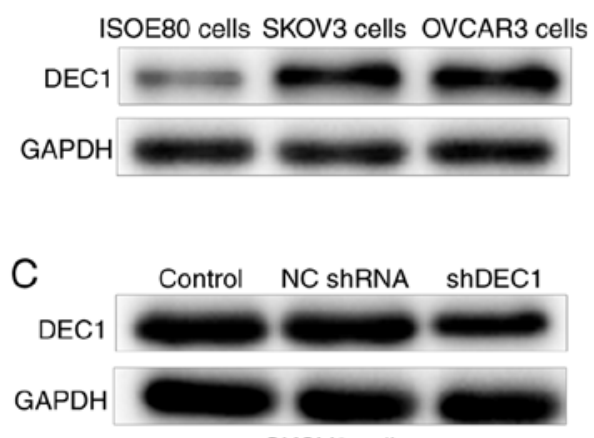

SKOV3 cells

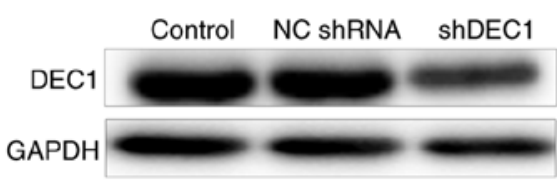

OVCAR3 cells

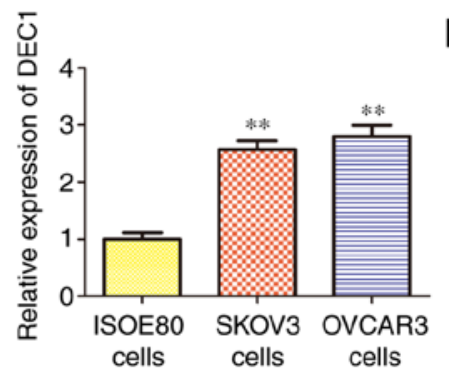

B j
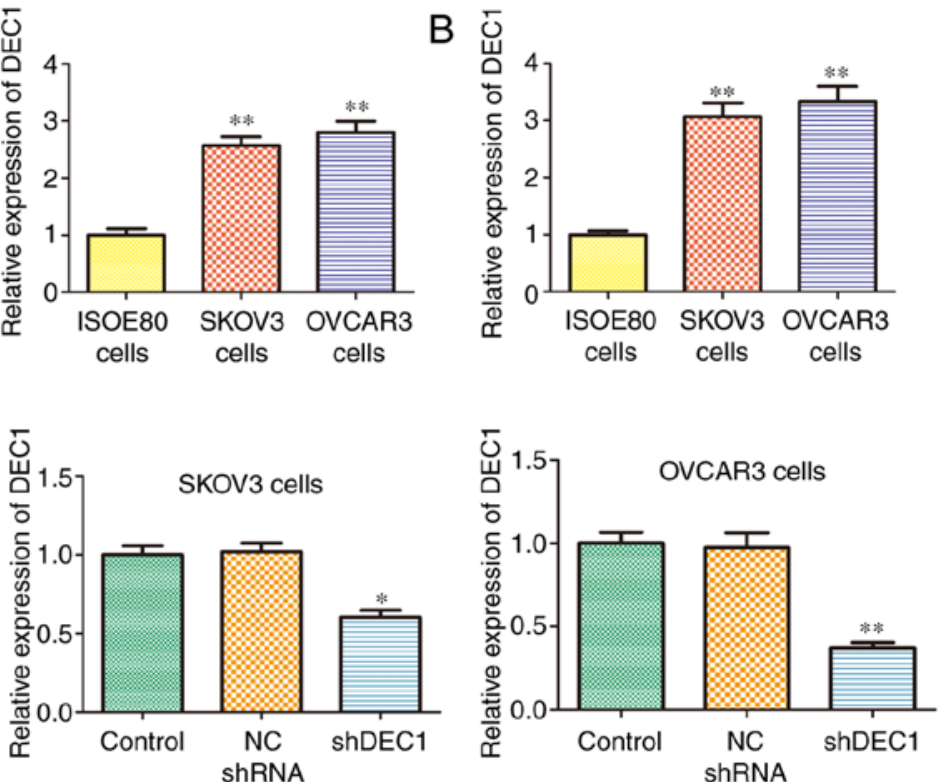

Figure 2. DEC1 is upregulated in OC cell lines. Expression of DEC1 in OC cell lines SKOV3 and OVCAR3 and ovarian epithelial cell line (ISOE80) was detected using (A) western blotting and (B) reverse transcription-quantitative PCR. (C) Expression of DEC1 in SKOV3 and OVCAR3 cells transfected with NC shRNA or shDEC1 was evaluated using western blotting. ${ }^{*} \mathrm{P}<0.05,{ }^{* *} \mathrm{P}<0.01$ vs. ISO80 cells or control (NC) group. NC, negative control; shRNA, short hairpin RNA; DEC1, differential embryo-chondrocyte expressed gene 1; OC, ovarian cancer.

number of EdU positive cells (Fig. 3C and D). These data indicated that DEC1 knockdown inhibited the proliferation of SKOV3 and OVCAR3 cells.
Knockdown of DECl induces apoptosis of OC cells. The effects of DEC1 on apoptosis of SKOV3 and OVCAR3 cells were evaluated using TUNEL assay, and the results 

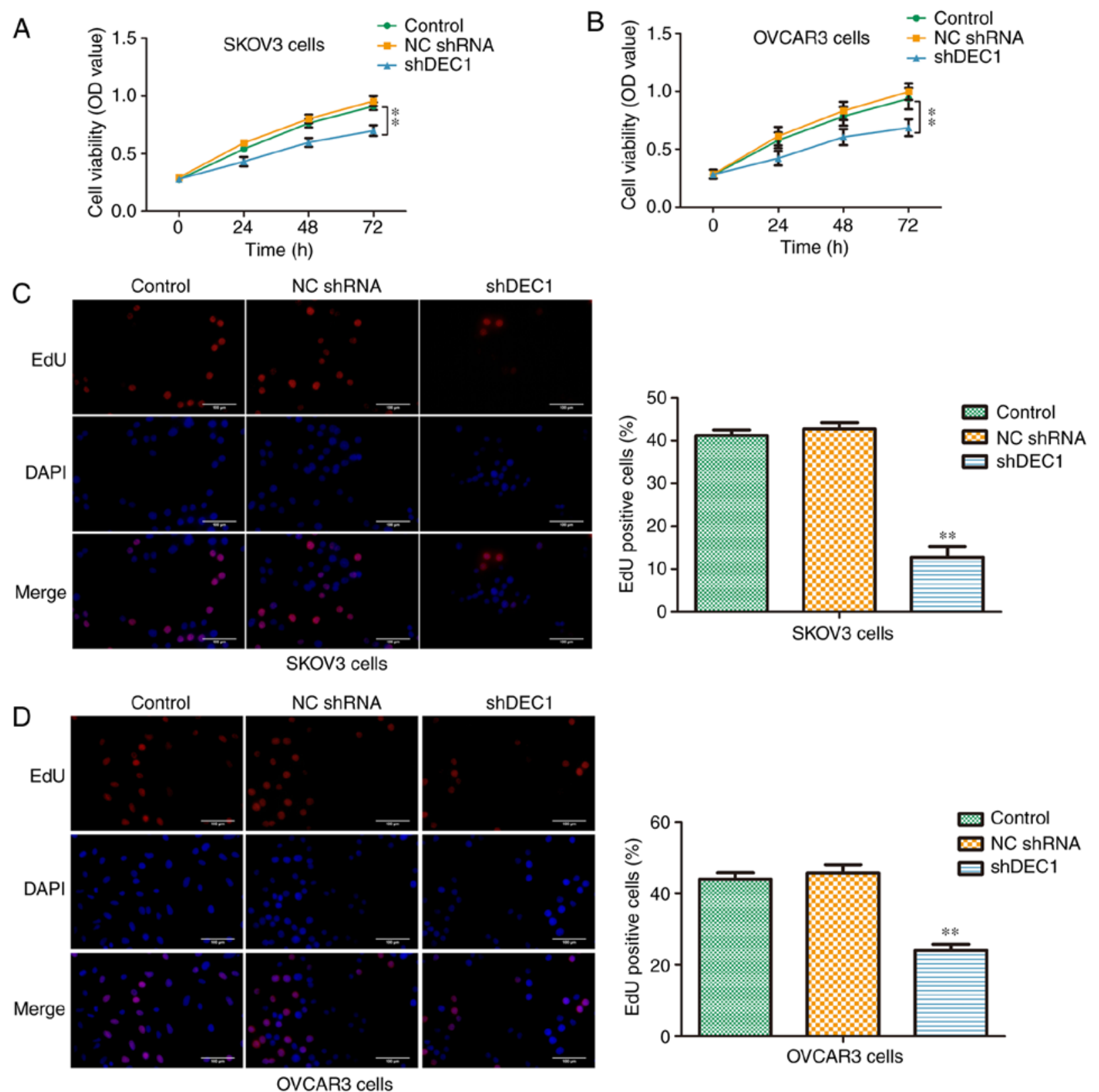

Figure 3. Knockdown of DEC1 inhibits proliferation of ovarian cancer cells. Cell Counting Kit-8 assay was performed to evaluate the effects of DEC1 on the viabilities in (A) SKOV3 and (B) OVCAR3 cells. EdU assay was performed to evaluate effects of DEC1 on proliferation in (C) SKOV3 and (D) OVCAR3 cells. Scale bars, $50 \mu \mathrm{m}$. ${ }^{* *} \mathrm{P}<0.01$ vs. control (NC) group. OD, optical density; NC, negative control; shRNA, short hairpin RNA; DEC1, differential embryochondrocyte expressed gene 1 .

demonstrated that inhibition of DEC1 significantly increased apoptosis in these cells compared with the control group (Fig. 4A and B).

Furthermore, western blotting was conducted to examine the role of shDEC1 in apoptotic-related proteins including caspase-3, cleaved-caspase-3, PARP and cleaved-PARP. Knockdown of DEC1 significantly increased the expression levels of cleaved-caspase-3 and cleaved-PARP in both SKOV3 and OVCAR3 cells (Fig. 4C and D). Therefore, it was identified that DEC1 knockdown promoted apoptosis of SKOV3 and OVCAR3 cells.

Knockdown of DECl inhibits migration and invasion of $O C$ cells. To investigate the potential role of shDEC1 in migration and invasion of OC cells, wound healing and Transwell invasion analysis were performed. The wounding healing rates in shDEC1 group were reduced compared with the control group in both SKOV3 and OVCAR3 cells (Fig. 5A and B). Moreover, the results of the Transwell invasion assay (Fig. 5C and D) indicated that after transfection with shDEC1, the invaded cell numbers were significantly suppressed compared with the control group.

Epithelial-mesenchymal transition (EMT) provides invasive and motile abilities for OC cells, and is considered to be an important factor in invasion and metastasis (28). Thus, western blotting was conducted to evaluate the effects of shDEC1 on the expression levels of E-cadherin, vimentin and $\alpha$-SMA. It was identified that knockdown of DEC1 
A
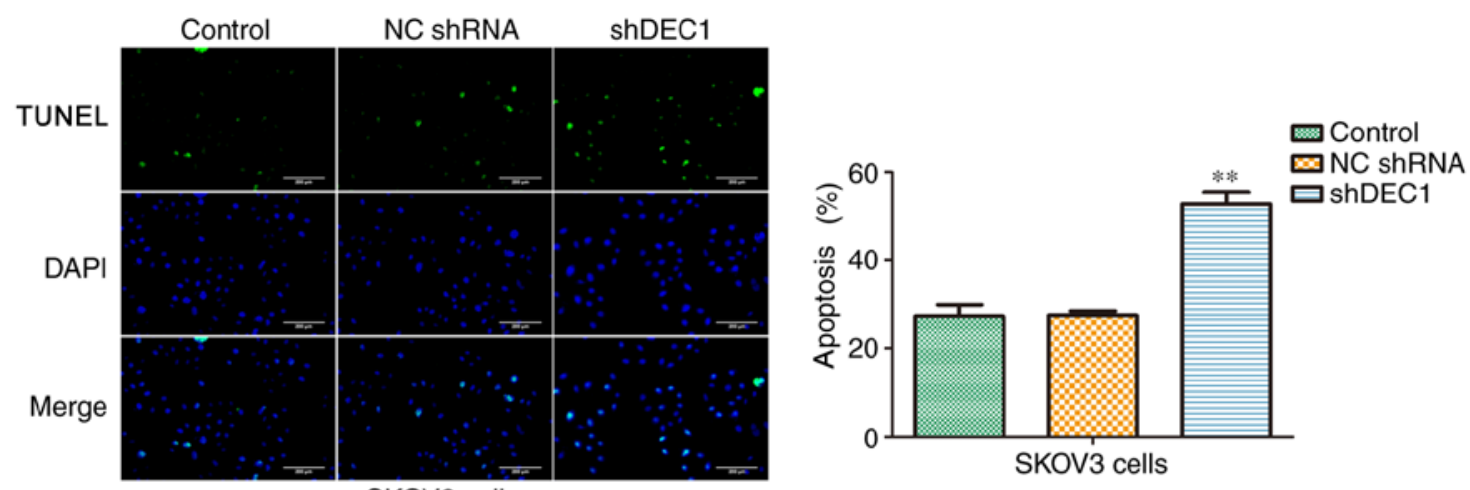

B
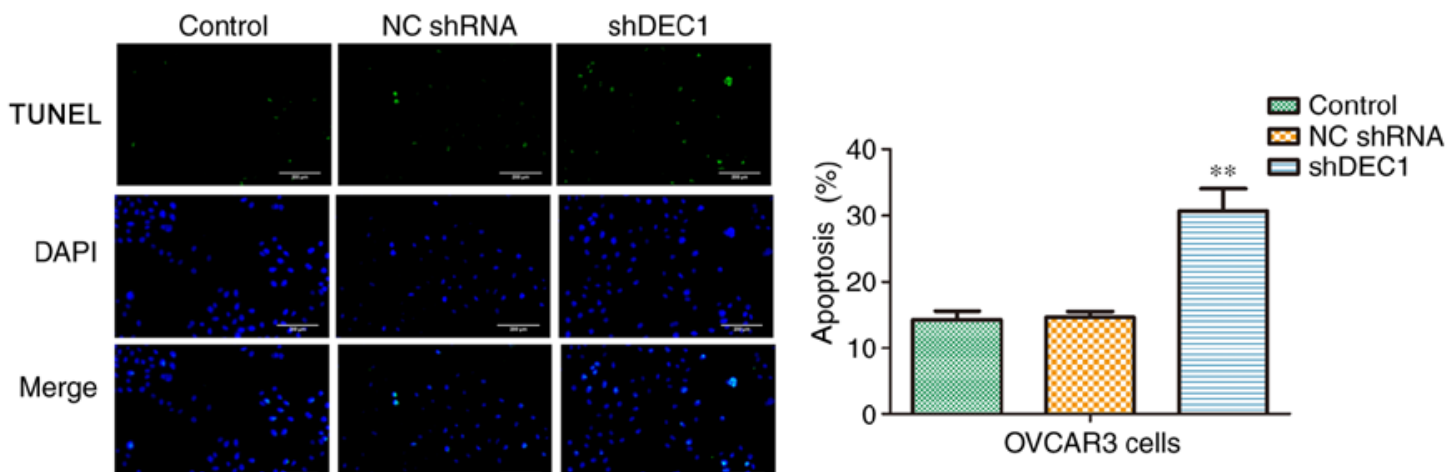

Merge
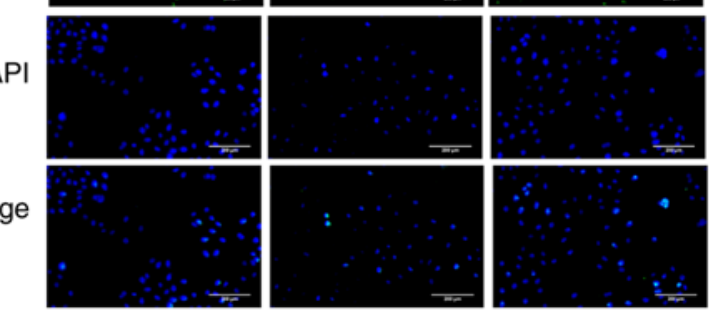

OVCAR3 cells
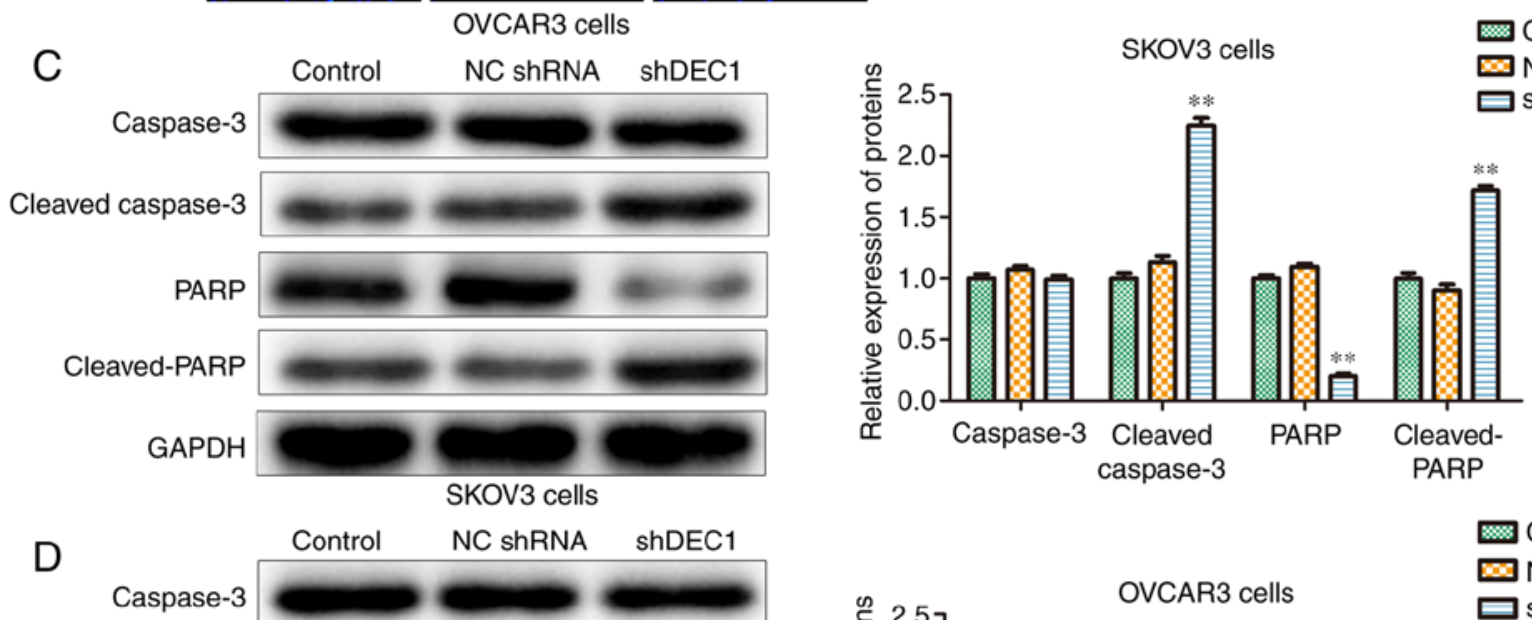

Cleaved caspase-3
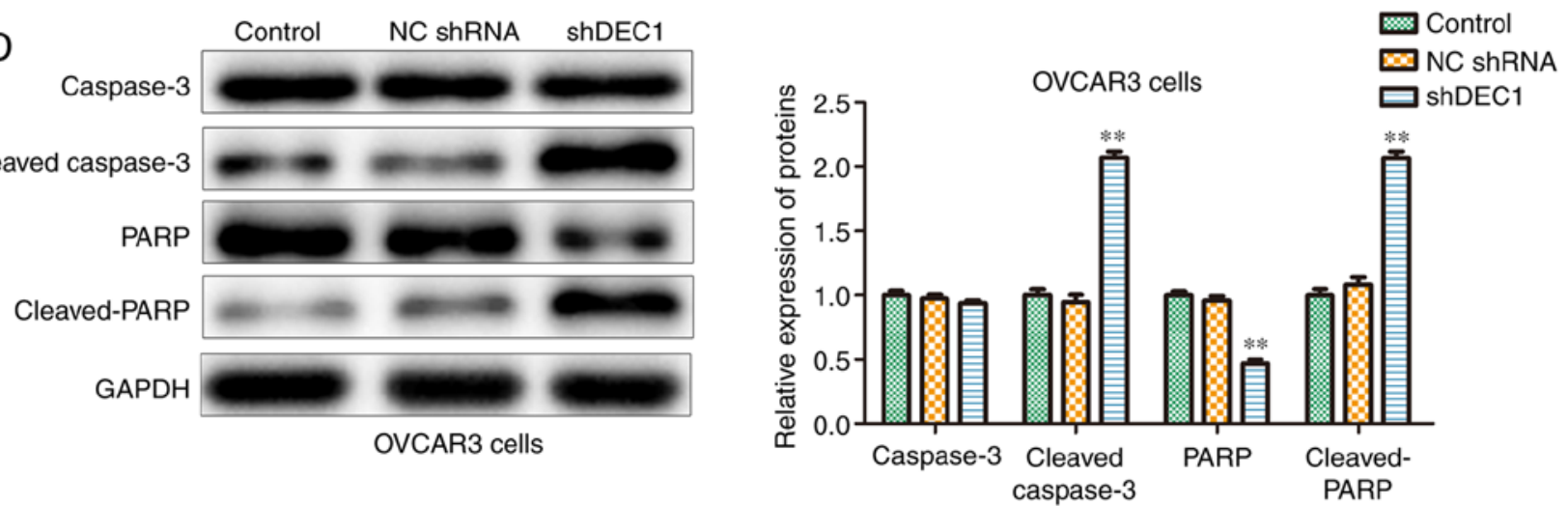

Figure 4. Knockdown of DEC1 induces apoptosis of ovarian cancer cells. TUNEL assay was performed to evaluate the effects of DEC1 on apoptosis in DEC1 on (A) SKOV3 and (B) OVCAR3 cells. Scale bars, $200 \mu \mathrm{m}$. Western blotting was performed to evaluate the effects of DEC1 on the apoptosis-related proteins in (C) SKOV3 and (D) OVCAR3 cells. ${ }^{* *} \mathrm{P}<0.01$ vs. control (NC) group. NC, negative control; shRNA, short hairpin RNA; DEC1, differential embryo-chondrocyte expressed gene 1; PARP, poly(ADP-ribose) polymerase 1.

significantly increased the expression of E-cadherin, but significantly decreased the expression levels of vimentin and $\alpha$-SMA in both cell types (Fig. 5E and F). Therefore, the results suggested that DEC1 knockdown inhibited the migration and invasion of SKOV3 and OVCAR3 cells.
Knockdown of DECl inhibits the Wnt/ $\beta$-catenin signaling pathwayofOC cells. The occurrence and development of tumors are regulated by numerous factors, among which abnormally activated cell signaling pathways serve a crucial role (29). For example, the Wnt/ $\beta$-catenin signaling pathway participates in 

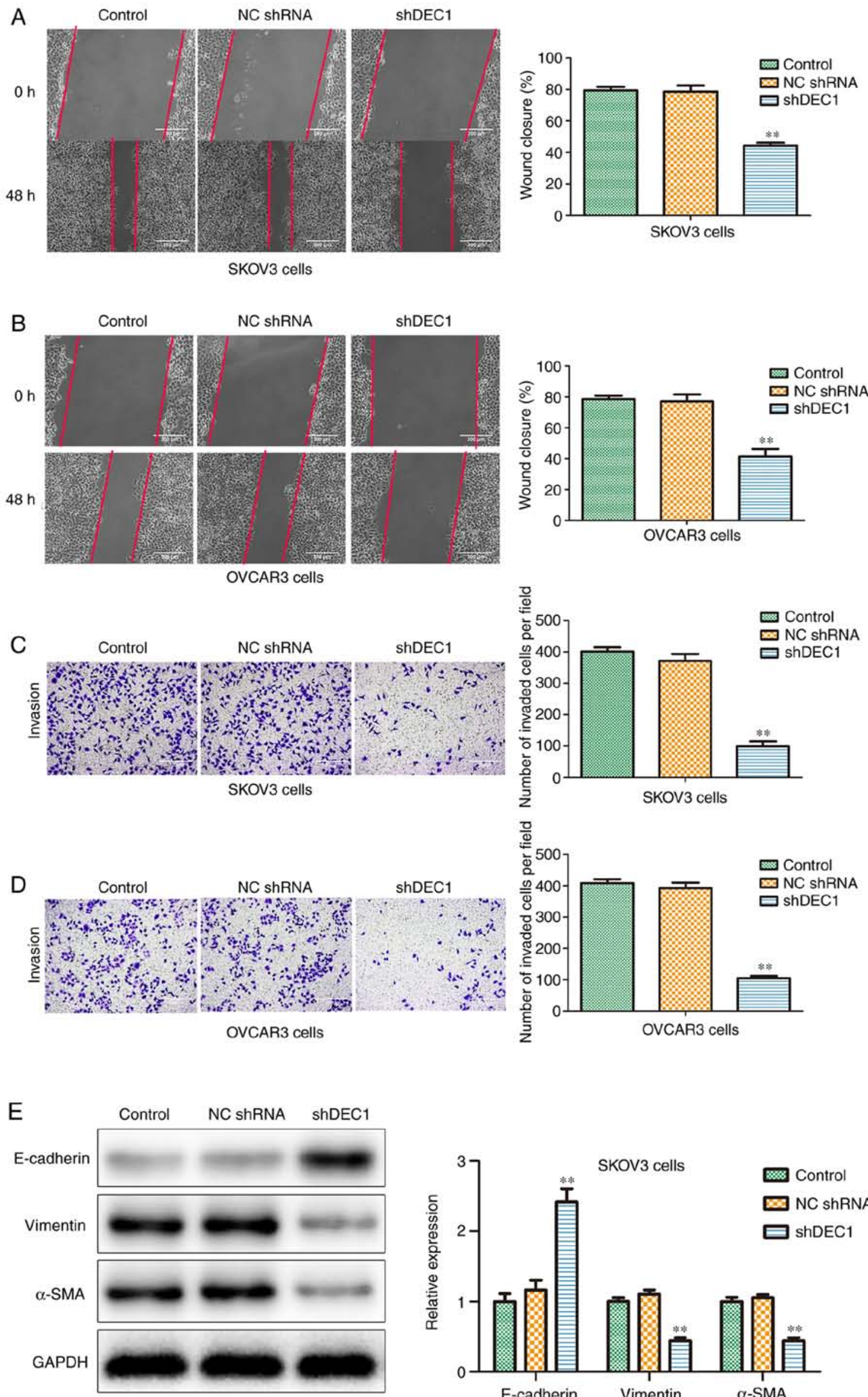

SKOV3 cells

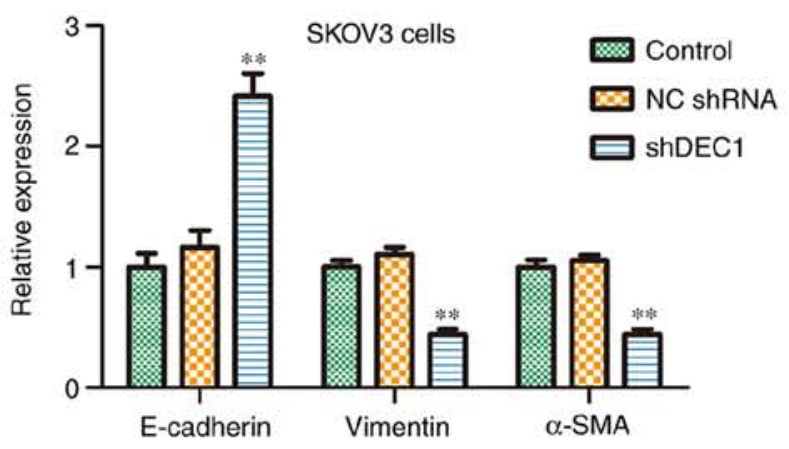

Figure 5. Continued 

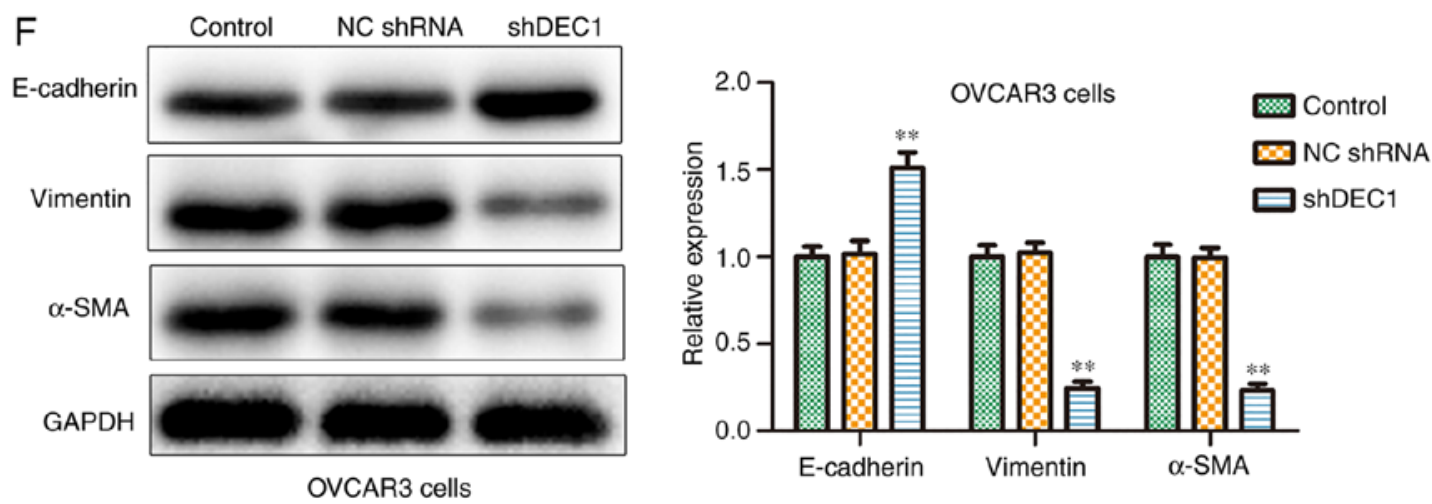

Figure 5. Continued. Knockdown of DEC1 inhibits migration and invasion of ovarian cancer cells. Wound healing assay was performed to evaluate the effects of DEC1 on migration in (A) SKOV3 and (B) OVCAR3 cells. Scale bar, $300 \mu \mathrm{m}$. Transwell invasion assay was performed to evaluate the effects of DEC1 on invasion in (C) SKOV3 and (D) OVCAR3 cells. Scale bars, $300 \mu \mathrm{m}$. Western blotting was conducted to evaluate the effects of DEC1 on the epithelial-mesenchymal transition-related proteins in (E) SKOV3 and (F) OVCAR3 cells. ${ }^{* *} \mathrm{P}<0.01$ vs. control (NC) group. NC, negative control; shRNA, short hairpin RNA; DEC1, differential embryo-chondrocyte expressed gene 1; $\alpha$-SMA, $\alpha$-smooth muscle actin.

the occurrence of various human tumors, including OC (30). Therefore, western blotting was used to assess the effects of shDEC1 on the expression of the Wnt//-catenin pathway, and the results demonstrated that inhibition of DEC1 significantly inhibited the expression levels of p-GSK-3 $\beta$ and $\beta$-catenin in SKOV3 and OVCAR3 cells (Fig. 6A and B).

\section{Discussion}

$\mathrm{OC}$ is common form of malignant tumors worldwide, and the molecular mechanisms of OC occurrence and development have been a hot topic in life science research $(31,32)$. Changes in the expression levels of tumor-related genes or specific genes, and activation of multiple signal transduction proteins and transcription factors can lead to the occurrence and development of OC (33). Among these, transcription factors exhibit key effects on regulating the growth, evolution and metastasis of OC by modulating oncogenes and tumor suppressor genes (34). Previous studies have reported that DEC1 is highly expressed in several tumors, and regulates the expression of genes closely associated with cancer via its complex transcriptional regulatory network. For instance, DEC1 expression is corrected with the malignancy and invasiveness of breast cancer, and high expression of DEC1 is positively associated with the grade of breast cancer (35). Moreover, the expression of DEC1 in oral squamous cell carcinoma is higher compared with healthy oral mucosa (36). It has also been shown that DEC1 expression is highest in recurrent oral squamous cell carcinoma within 1 year and lowest in non-recurrent oral squamous cell carcinoma within 3 years, indicating that DEC1 is negatively correlated with the prognosis of oral squamous cell carcinoma (36). DEC1 affects the progression of gastric cancer by upregulating hypoxia inducible factor 1 subunit $\alpha$ (37), and overexpression of DEC1 can enhance reactive oxygen species to activate the PI3K/Akt signaling pathway (10). The results of the present study indicated that DEC1 was upregulated in OC tissues and cell lines, and the expression of DEC1 was negatively associated to the prognosis of patients with OC.

Malignant proliferation is one of the important biological characteristics of cancer cells (38). OC has a malignant phenotype involving infinite proliferation and anti-apoptosis (39).
In the malignant development of OC, abnormal expression levels of multiple genes lead to cell proliferation, apoptosis reduction and cell dedifferentiation, which eventually lead to uncontrolled cell proliferation $(40,41)$. A previous study has shown that silencing DEC1 inhibited the proliferation of breast cancer by inducing cell cycle arrest in S phase (17). Similarly, the current findings demonstrated that knockdown of DEC1 inhibited OC cell proliferation, using CCK- 8 and EdU assay.

Apoptosis is an autonomous and orderly cell death involving the activation, expression and regulation of a series of genes under physiological or pathological conditions (42). In the present study, knockdown of DEC1 induced apoptosis of OC cells, as well as the expression of cleaved-caspase-3 and cleaved-PARP proteins, which was consistent with the results of $\mathrm{Li}$ et al (43), who reported that downregulation of DEC1 can inhibit the apoptosis induced by serum starvation in colon cancer cells and selectively inhibit the activities of caspases-3, 7 and 9.

Cell metastasis has positive role in embryonic development, maintaining homeostasis of intracellular environment, wound healing and other physiological functions, and is also associated with pathophysiological processes such as cancer metastasis (44). The process of metastasis is involved in changes of cell structure, cytoskeleton dynamics, expression levels of adhesion molecules and activation of signals necessary for cell migration $(45,46)$. Therefore, the migration and invasion of cancer cells are a complex process involving multiple genes, steps and factors. A previous study revealed that transforming growth factor- $\beta$ induced PANC- 1 cells to gain a spindle-shaped morphology, while treatment with shDEC1 reversed the effects and inhibited the migration and invasion of PANC-1 cells (47), which was in line with the present results. In the present study, it was found that knockdown of DEC1 suppressed the migration and invasion of OC cells.

EMT is a reversible biological process involving changes in cell morphology and features (48). In the process of EMT, the expression levels of epithelial markers, such as E-cadherin and keratin, are upregulated, while the expression levels of interstitial markers, such as vimentin and $\mathrm{N}$-cadherin, are increased. These effects subsequently lead to increased 

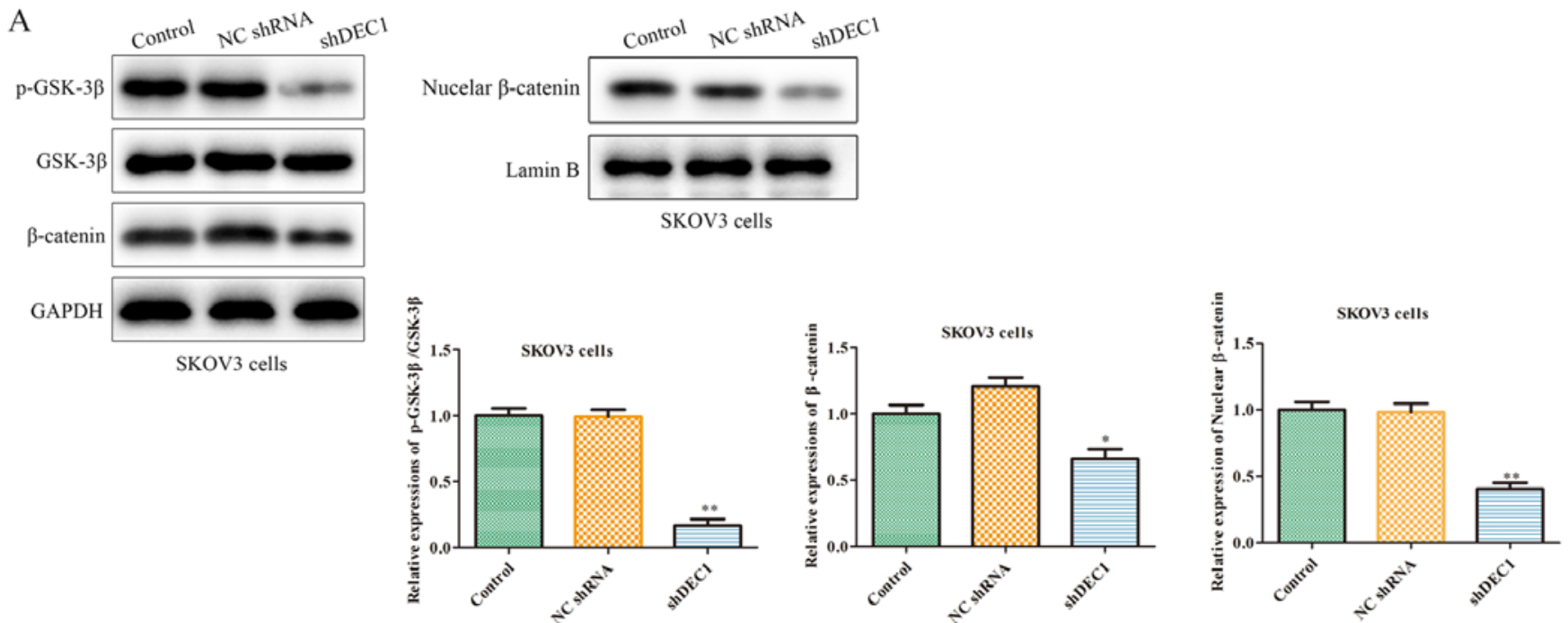

B
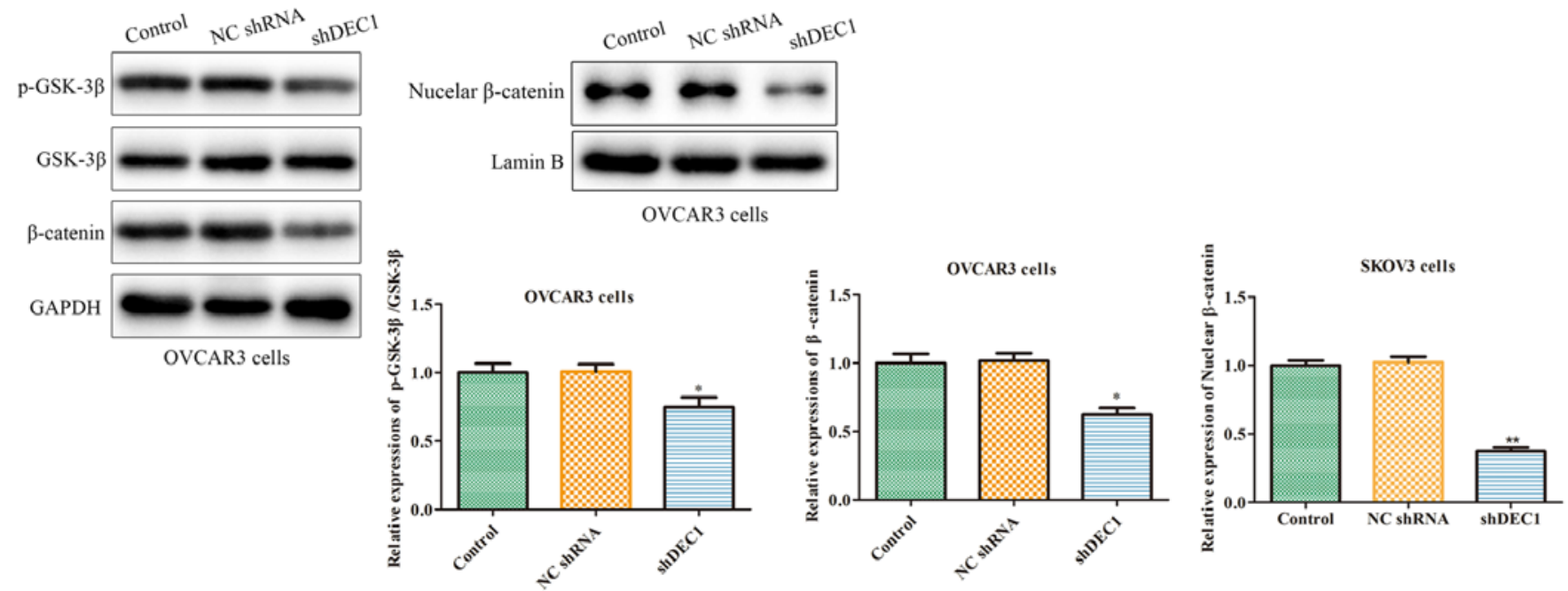

Figure 6. Knockdown of DEC1 inhibits the Wnt/ $\beta$-catenin signaling pathway of ovarian cancer cells. Western blotting was performed to evaluate the effects of DEC1 on expression of the Wnt/ $\beta$-catenin signaling pathway in (A) SKOV3 and (B) OVCAR3 cells. ${ }^{*} \mathrm{P}<0.05,{ }^{* *} \mathrm{P}<0.01$ vs. control group. NC, negative control; shRNA, short hairpin RNA; DEC1, differential embryo-chondrocyte expressed gene 1; p-, phosphorylated; GSK-3 $\beta$, glycogen synthase kinase $3 \beta$.

secretion of MMPs and extracellular matrix proteins, as well as the destruction of basement membrane and extracellular matrix (49). Moreover, EMT in epithelial cell tumors provides invasive and motile abilities for tumor cells, and is considered to be an essential factor in invasion and metastasis (50). Therefore, the effects of EMT in the invasion and metastasis of cancer, including $\mathrm{OC}$, and its regulation mechanisms have gained increased attention in recent years. In the present study, it was demonstrated that knockdown of DEC1 significantly decreased the migratory and invasive abilities of OC cells.

The Wnt/ $\beta$-catenin pathway is highly conserved in the evolutionary process and participates in the regulation of cell proliferation and differentiation during embryonic development (51). $\beta$-catenin, as an oncogene and a component of the Wnt signaling transduction pathway, accumulates in the nucleus and forms a complex with TCF/LEF of DNA-binding transcription factor family to enhance the expression of various genes, which not only promotes the proliferation of cancer cells, but also activates the transcriptional expressions of several genes, such as endoplasmic reticulum membrane protein complex proteins, fibronectin and MMPs, so that tumor cells are loose and prone to invasion and metastasis $(52,53)$. Furthermore, there is no Wnt signal in healthy mature cells, and only a small amount of $\beta$-catenin is free in cells; some of which is phosphorylated by GSK-3 $\beta$ (54). Rask et al (55) detected and localized $\beta$-catenin and other members of the Wnt family using immunohistochemistry and western blotting, and revealed that members of the Wnt family, including $\beta$-catenin, were expressed in healthy human ovarian epithelial cells and the epithelial ovarian cancer cell line OVCAR3, while the nuclear staining of $\beta$-catenin was only expressed in OVCAR3 cells (55). These results indicated that $\beta$-catenin was located in the cell membrane in healthy cells. When the Wnt pathway is activated, the activity of GSK- $3 \beta$ is inhibited, and thus $\beta$-catenin cannot be phosphorylated and degraded. Therefore, $\beta$-catenin aggregates and moves into the nucleus, stimulating the expression levels of a series of oncogenes, which affects the progression of tumors (56). In the present 
study, it was demonstrated that knockdown of DEC1 inhibited the $\mathrm{Wnt} / \beta$-catenin pathway.

In conclusion, the present study identified that DEC1 was highly expressed in OC tissues and cell lines, and high expression of DEC1 was positively associated with the prognosis of patients with OC. Moreover, knockdown of DEC1 inhibited the proliferation, migration and invasion, and induced apoptosis of OC cells, which may be achieved by modulating the Wnt/ $\beta$-catenin pathway. However, in the experimental design of the present study only SKOV3 and OVCAR3 cell lines were included, and additional ovarian cancer cells should be investigated in future studies.

\section{Acknowledgements}

Not applicable.

\section{Funding}

No funding was received.

\section{Availability of data and materials}

The datasets used and/or analyzed during the current study are available from the corresponding author on reasonable request.

\section{Authors' contributions}

YYi, BT and XinY conceived and designed the study. YYi, BL, ZZ, XiaY, YZ and YYa performed the literature search and acquisition of data. YYi, BL, ZZ and XiaY contributed to the analysis and interpretation of data. YYi and BT drafted and revised the manuscript. All authors read and approved the final manuscript.

\section{Ethics approval and consent to participate}

This study has obtained approval from the Jiangxi Cancer Hospital Medical Ethics Committee and oral informed consent from all patients.

\section{Patient consent for publication}

Not applicable.

\section{Competing interests}

The authors declare that they have no competing interests.

\section{References}

1. Norouzi-Barough L,SarookhaniMR,Sharifi M,MoghbelinejadS, Jangjoo S and Salehi R: Molecular mechanisms of drug resistance in ovarian cancer. J Cell Physiol 233: 4546-4562, 2018.

2. Wang H, Xu T, Zheng L and Li G: Angiogenesis inhibitors for the treatment of ovarian cancer: An updated systematic review and meta-analysis of randomized controlled trials. Int J Gynecol Cancer 28: 903-914, 2018.

3. Siegel RL, Miller KD and Jemal A: Cancer statistics, 2019. CA Cancer J Clin 69: 7-34, 2019.

4. Hirte HW: Profile of erlotinib and its potential in the treatment of advanced ovarian carcinoma. Onco Targets Ther 6: 427-435, 2013.
5. Du Bois A and Pfisterer J: Future options for first-line therapy of advanced ovarian cancer. Int J Gynecol Cancer (Suppl 1): S42-S50, 2005.

6. Miller KD, Siegel RL, Lin CC, Mariotto AB, Kramer JL, Rowland JH, Stein KD, Alteri R and Jemal A: Cancer treatment and survivorship statistics, 2016. CA Cancer J Clin 66: 271-289, 2016.

7. Torre LA, Trabert B, DeSantis CE, Miller KD, Samimi G, Runowicz CD, Gaudet MM, Jemal A and Siegel RL: Ovarian cancer statistics, 2018. CA Cancer J Clin 68: 284-296, 2018.

8. Sato $\mathrm{S}$ and Itamochi $\mathrm{H}$ : Neoadjuvant chemotherapy in advanced ovarian cancer: Latest results and place in therapy. Ther Adv Med Oncol 6: 293-304, 2014.

9. Bhawal UK, Sato F, Arakawa Y, Fujimoto K, Kawamoto T, Tanimoto K, Ito Y, Sasahira T, Sakurai T, Kobayashi M, et al: Basic Helix-loop-helix transcription factor DEC1 negatively regulates cyclin D1. J Pathol 224: 420-429, 2011.

10. Kato Y, Kawamoto T, Fujimoto $K$ and Noshiro $M$ : DEC1/STRA13/SHARP2 and DEC2/SHARP1 coordinate physiological processes, including circadian rhythms in response to environmental stimuli. Curr Top Dev Biol 110: 339-372, 2014.

11. Miyazaki K, Miyazaki M, Guo Y, Yamasaki N, Kanno M, Honda $\mathrm{Z}$, Oda $\mathrm{H}$, Kawamoto $\mathrm{H}$ and Honda $\mathrm{H}$ : The role of the basic Helix-loop-helix transcription factor Dec1 in the regulatory T cells. J Immunol 185: 7330-7339, 2010.

12. Liu Y, Wang L, Lin XY, Wang J, Yu JH, Miao Y and Wang EH: The transcription factor DEC1 (BHLHE40/STRA13/SHARP-2) is negatively associated with TNM stage in non-small-cell lung cancer and inhibits the proliferation through cyclin D1 in A549 and BE1 cells. Tumour Biol 34: 1641-1650, 2013.

13. Xu Q, Ma P, Hu C, Chen L, Xue L, Wang Z, Liu M, Zhu H, $\mathrm{Xu} \mathrm{N}$ and $\mathrm{Lu} \mathrm{N}$ : Overexpression of the DEC1 protein induces senescence in vitro and is related to better survival in esophageal squamous cell carcinoma. PLoS One 7: e41862, 2012.

14. Jia Y, Hu R, Li P, Zheng Y, Wang Y and Ma X: DEC1 is required for anti-apoptotic activity of gastric cancer cells under hypoxia by promoting Survivin expression. Gastric Cancer 21: 632-642, 2018.

15. Murakami K, Wu Y, Imaizumi T, Aoki Y, Liu Q, Yan X, Seino H, Yoshizawa T, Morohashi S, Kato Y and Kijima H: DEC1 promotes hypoxia-induced epithelial-mesenchymal transition (EMT) in human hepatocellular carcinoma cells. Biomed Res 38: 221-227, 2017.

16. Bi H, Li S, Qu X, Wang M, Bai X, Xu Z, Ao X, Jia Z, Jiang X, Yang $\mathrm{Y}$ and $\mathrm{Wu} \mathrm{H}$ : DEC1 regulates breast cancer cell proliferation by stabilizing cyclin E protein and delays the progression of cell cycle S phase. Cell Death Dis 6: e1891, 2015.

17. Hu J, Mao Z, He S, Zhan Y, Ning R, Liu W, Yan B and Yang J: Icariin protects against glucocorticoid induced osteoporosis, increases the expression of the bone enhancer DEC1 and modulates the PI3K/Akt/GSK3 $\beta / \beta$-catenin integrated signaling pathway. Biochem Pharmacol 136: 109-121, 2017.

18. Zhu Z, Wang YW, Ge DH, Lu M, Liu W, Xiong J, Hu G, Li XP and Yang J: Downregulation of DEC1 contributes to the neurotoxicity induced by MPP $(+)$ by suppressing PI3K/Akt/GSK3 $\beta$ pathway. CNS Neurosci Ther 23: 736-747, 2017.

19. Shi J, Zhu Q, Wu J and Zhu P: FAM46C suppresses gastric cancer by inhibition of Wnt/beta-catenin. Front Biosci (Landmark Ed) 25: 549-563, 2020.

20. Zhang C, Zhang Z, Zhang S, Wang W and Hu P: Targeting of Wnt/ $\beta$-catenin by anthelmintic drug pyrvinium enhances sensitivity of ovarian cancer cells to chemotherapy. Med Sci Monit 23: 266-275, 2017.

21. Hu Z, Wang P, Lin J, Zheng X, Yang F, Zhang G, Chen D, Xie J, Gao Z, Peng L and Xie C: MicroRNA-197 Promotes metastasis of hepatocellular carcinoma by activating wnt/ $\beta$-catenin signaling. Cell Physiol Biochem 51: 470-486, 2018.

22. Kumar R, Kotapalli V, Naz A, Gowrishankar S, Rao S, Pollack JR and Bashyam MD: XPNPEP3 is a novel transcriptional target of canonical Wnt $/ \beta$-catenin signaling. Genes Chromosomes Cancer 57: 304-310, 2018.

23. Wang Y, Lei L, Zheng YW, Zhang L, Li ZH, Shen HY, Jiang GY, Zhang XP, Wang EH and Xu HT: Odd-skipped related 1 inhibits lung cancer proliferation and invasion by reducing Wnt signaling through the suppression of SOX9 and $\beta$-catenin. Cancer Sci 109: 1799-1810, 2018.

24. Raghavan S, Mehta P, Xie Y, Lei YL and Mehta G: Ovarian cancer stem cells and macrophages reciprocally interact through the WNT pathway to promote pro-tumoral and malignant phenotypes in 3D engineered microenvironments. J Immunother Cancer 7: 190, 2019. 
25. Kim MS, Cho HI, Yoon HJ, Ahn YH, Park EJ, Jin YH and Jang YK: JIB-04, A Small molecule histone demethylase inhibitor, selectively targets colorectal cancer stem cells by inhibiting the wnt/ $\beta$-catenin signaling pathway. Sci Rep 8: 6611, 2018.

26. Zhou L, Rui JA, Ye DX, Wang SB, Chen SG and Qu Q: Edmondson-Steiner grading increases the predictive efficiency of TNM staging for long-term survival of patients with hepatocellular carcinoma after curative resection. World J Surg 32: 1748-1756, 2008.

27. Livak KJ and Schmittgen TD: Analysis of relative gene expression data using real-time quantitative PCR and the 2(-Delta Delta C(T)) method. Methods 25: 402-408, 2001.

28. Zhou J, Du Y, Lu Y, Luan B, Xu C, Yu Y and Zhao H: CD44 expression predicts prognosis of ovarian cancer patients through promoting Epithelial-mesenchymal transition (EMT) by regulating snail, ZEB1, and caveolin-1. Front Oncol 9: 802, 2019.

29. Gonçalves V, Pereira JFS and Jordan P: Signaling pathways driving aberrant splicing in cancer cells. Genes (Basel) 9: 9, 2018.

30. Arend RC,Londoño-Joshi AI, Straughn JM Jr and Buchsbaum DJ: The Wnt/ß-catenin pathway in ovarian cancer: A review. Gynecol Oncol 131: 772-779, 2013.

31. Yeung TL, Leung CS, Yip KP, Au Yeung CL, Wong ST and Mok SC: Cellular and molecular processes in ovarian cancer metastasis. A review in the theme: Cell and molecular processes in cancer metastasis. Am J Physiol Cell Physiol 309: C444-C456, 2015.

32. Grunewald $\mathrm{T}$ and Ledermann JA: Targeted therapies for ovarian cancer. Best Pract Res Clin Obstet Gynaecol 41: 139-152, 2017.

33. Kroeger PT Jr and Drapkin R: Pathogenesis and heterogeneity of ovarian cancer. Curr Opin Obstet Gynecol 29: 26-34, 2017.

34. Kaldawy A, Segev Y, Lavie O, Auslender R, Sopik V and Narod SA: Low-grade serous ovarian cancer: A review. Gynecol Oncol 143: 433-438, 2016.

35. Liu Y, Miao Y, Wang J, Lin X, Wang L, Xu HT and Wang EH: DEC1 is positively associated with the malignant phenotype of invasive breast cancers and negatively correlated with the expression of claudin-1. Int J Mol Med 31: 855-860, 2013.

36. You J, Lin L, Liu Q, Zhu T, Xia K and Su T: The correlation between the expression of differentiated embryo-chondrocyte expressed gene 1 and oral squamous cell carcinoma. Eur J Med Res 19: 21, 2014.

37. Yan Z, Shi X, Min W, Jia Y, Li B, Zhang Y, Liu Q and Wang Y: The increased expression of DEC1 gene is related to HIF-1 $\alpha$ protein in gastric cancer cell lines. Mol Biol Rep 39: 4229-4236, 2012.

38. Czekierdowska S, Stachowicz N, Chróściel M and Czekierdowski A: Proliferation and maturation of intratumoral blood vessels in women with malignant ovarian tumors assessed with cancer stem cells marker nestin and platelet derived growth factor PDGF-B. Ginekol Pol 88: 120-128, 2017.

39. Wei ZT, Zhang X, Wang XY, Gao F, Zhou CJ, Zhu FL, Wang Q, Gao Q, Ma CH, Sun WS, et al: PDCD4 inhibits the malignant phenotype of ovarian cancer cells. Cancer Sci 100: 1408-1413, 2009.

40. Zuo K, Zhao Y, Zheng Y, Chen D, Liu X, Du S and Liu Q: Long non-coding RNA XIST promotes malignant behavior of epithelial ovarian cancer. Onco Targets Ther 12: 7261-7267, 2019.

41. Yu HL, Ma XD, Tong JF, Li JQ, Guan XJ and Yang JH: WTAP is a prognostic marker of high-grade serous ovarian cancer and regulates the progression of ovarian cancer cells. Onco Targets Ther 12: 6191-6201, 2019.

42. Twomey C and Mccarthy JV: Pathways of apoptosis and importance in development. J Cell Mol Med 9: 345-359, 2010.
43. Li Y, Zhang H, Xie M, Hu M, Ge S, Yang D, Wan Y and Yan B: Abundant expression of Dec1/stra13/sharp2 in colon carcinoma: Its antagonizing role in serum deprivation-induced apoptosis and selective inhibition of procaspase activation. Biochem J 367: 413-422, 2002.

44. Liu Y, Ren CC, Yang L, Xu YM and Chen YN: Role of CXCL12-CXCR4 axis in ovarian cancer metastasis and CXCL12-CXCR4 blockade with AMD3100 suppresses tumor cell migration and invasion in vitro. J Cell Physiol 234: 3897-3909, 2019.

45. Al Ameri W, Ahmed I, Al-Dasim FM, Ali Mohamoud Y, Al-Azwani IK, Malek JA and Karedath T: Cell type-specific TGF- $\beta$ mediated EMT in 3D and 2D models and its reversal by TGF- $\beta$ receptor kinase inhibitor in ovarian cancer cell lines. Int J Mol Sci 20: 3568, 2019.

46. Zhang H, Wang Y, Chen T, Zhang Y, Xu R, Wang W, Cheng M and Chen Q: Aberrant activation of hedgehog signalling promotes cell migration and invasion via matrix metalloproteinase-7 in ovarian cancer cells. J Cancer 10: 990-1003, 2019.

47. Wu Y, Sato F, Yamada T, Bhawal UK, Kawamoto T, Fujimoto K, Noshiro M, Seino H, Morohashi S, Hakamada K, et al: The BHLH transcription factor DEC1 plays an important role in the epithelial-mesenchymal transition of pancreatic cancer. Int J Oncol 41: 1337-1346, 2012.

48. Duan H, Yan Z, Chen W, Wu Y, Han J, Guo H and Qiao J: TET1 inhibits EMT of ovarian cancer cells through activating Wnt $/ \beta$-catenin signaling inhibitors DKK1 and SFRP2. Gynecol Oncol 147: 408-417, 2017.

49. Felipe Lima J, Nofech-Mozes S, Bayani J and Bartlett JM: EMT in breast carcinoma-a review. J Clin Med 5: 65, 2016.

50. Chen Y, Wang DD, Wu YP, Su D, Zhou TY, Gai RH, Fu YY, Zheng L, He QJ, Zhu H and Yang B: MDM2 promotes epithelial-mesenchymal transition and metastasis of ovarian cancer SKOV3 cells. Br J Cancer 117: 1192-1201, 2017.

51. Walston T, Tuskey C, Edgar L, Hawkins N, Ellis G, Bowerman B, Wood W and Hardin J: Multiple Wnt signaling pathways converge to orient the mitotic spindle in early $C$. elegans embryos. Dev Cell 7: 831-841, 2004.

52. Yang S, Liu Y, Li MY, Ng CSH, Yang SL, Wang S, Zou C, Dong Y, Du J, Long X, et al: FOXP3 promotes tumor growth and metastasis by activating Wnt/ $\beta$-catenin signaling pathway and EMT in non-small cell lung cancer. Mol Cancer 16: 124, 2017.

53. Wang H, Wu M, Lu Y, He K, Cai X, Yu X, Lu J and Teng L: LncRNA MIR4435-2HG targets desmoplakin and promotes growth and metastasis of gastric cancer by activating Wnt $/ \beta$-catenin signaling. Aging (Albany NY) 11: 6657-6673, 2019.

54. Smolders LA, Meij BP, Riemers FM, Licht R, Wubbolts R, Heuvel D, Grinwis GC, Vernooij HC, Hazewinkel HA, Penning LC and Tryfonidou MA: Canonical Wnt signaling in the notochordal cell is upregulated in early intervertebral disk degeneration. J Orthop Res 30: 950-957, 2012.

55. Rask K, Nilsson A, Brännström M, Carlsson P, Hellberg P, Janson PO, Hedin L and Sundfeldt K: Wnt-signalling pathway in ovarian epithelial tumours: Increased expression of beta-catenin and GSK3beta. Br J Cancer 89: 1298-1304, 2003.

56. Li J, Yin J, Shen W, Gao R, Liu Y, Chen Y, Li X, Liu C, Xiang R and Luo N: TLR4 promotes breast cancer metastasis via Akt/GSK3 $/ \beta$-catenin pathway upon LPS stimulation. Anat Rec (Hoboken) 300: 1219-1229, 2017.

This work is licensed under a Creative Commons Attribution-NonCommercial-NoDerivatives 4.0 International (CC BY-NC-ND 4.0) License. 